\title{
From Salon Romance to the Café-Concert Chanson: 19th-Century French Networks of Music Promotion and Consumption
}

\section{By Kimberly White and Cynthia Leive}

In 2007, the National Gallery of Canada approached the Marvin Duchow Music Library of McGill University seeking a possible new home for a collection of nineteenth-century French sheet music. The collection had been housed in the National Gallery for several years but was originally purchased by the then National Library of Canada (NLC) in the late 1960s in order to complement its holdings of British sheet music. The April-June 1969 edition of NL News publicized the acquisition and NLC files contain a photocopy of a description of the collection with the imprint Martinus Nijioff, Publisher and Bookseller, The Hague. ${ }^{1}$ It appears likely the collection was acquired through the assistance of Nijioff managing director and antiquarian specialist Anton Gerits. ${ }^{2}$ The one-page Nijioff advertisement totals the number of physical pieces in the collection published between 1825 and 1914 at 19,652 and divides the collection into the following categories:

9969 complete songs (music, text, front page lithography)

7721 front page lithography only

1962 lithographic proof print plates (sheet music illustrations)

It goes on to state that among the complete songs, a wide range of genres was represented including berceuses, quadrilles, chansons à boire, élégies, ballades, chansons de circonstances, chansons d'amour, and danses.

The McGill Music Library decided it was interested in the collection because of the Schulich School of Music research strength in nineteenth- and early twentieth-century French art music led by Professor Steven Huebner ${ }^{3}$ and his graduate students, as a complement to the Music Library's collection of twentieth-century French popular sheet music, and because of its

Kimberly White (PhD, McGill University) holds a postdoc from the Fonds de recherche du Québec - Société et Culture (FQRSC) and will be carrying out her postdoctoral research at the University of Southampton from 2013 to 2015. Cynthia Leive is Head of the Marvin Duchow Music Library of McGill University.

1. Thanks to Richard Green and his colleagues at Library and Archives Canada for this background information.

2. Arts et Métiers du livre, no. 156 (juin-julllet-août 1989), 40.

3. See http://www.mcgill.ca/music/about-us/bio/steven-huebner 
potential to be an important source of research for Quebec music scholars in general. Beginning in winter 2012, the collection was unpacked and organized. An assessment of its physical condition included the formulation of a plan for removing $50 \%$ of the complete songs from highly acidic paper (unfortunately attached to the tips of all four corners of each sheet with water-based glue) and for long-term storage. Houman Behzadi, a McGill School of Information Studies graduate student, blogged ${ }^{4}$ about the collection in August 2012 and provided basic information about its contents in a session at the annual meeting (November 2012) of the Quebec Chapter of CAML.

\section{Commercial sheet music production and circulation in 19th-century France}

In December 2012, post-doctoral musicologist Kimberly White began a detailed examination of the collection which has revealed a wealth of popular music genres and subgenres as well as arrangements of "high art" forms intended for popular audiences. The collection includes a large number of romances typically performed in bourgeois and aristocratic salons as well as chansons popularized in new music venues, such as the café-concert, the cabaret artistique and the music-hall. The romance became a popular vocal genre in the late-eighteenth and earlynineteenth centuries: its strophic form, simple and tuneful melody, relatively narrow vocal compass and sentimental text made it ideal for performance in opéra-comique as well as in amateur music-making. The romance's popularity was enhanced significantly with the development of commercial print technologies: demand increased as it became possible to produce an increasingly larger number of works. The considerable production and wide circulation of the romance-indeed, its saturation of the market-might be considered an important factor in the eventual broadening of the genre into various subgenres by midcentury $^{5}$ and certainly an impetus for the development of the chanson that came to dominate the popular music market in the second half of the century.

By the mid-nineteenth century, French commercial sheet music production was a flourishing industry; in 1866, Arthur Pougin estimated 5,000 new pieces were produced in a single year, from September 1864 to August $1865 .{ }^{6}$ Sheet music in France was generally produced in two sizes: the "grand format," measuring $26 \mathrm{~cm}$ x $33 \mathrm{~cm}$, and the "petit format," measuring

4. See http://blogs.library.mcgill.ca/music-flipside/2012/08/22/sibley-music-librarys-preservation-workshopand-a-mcgill-music-library-sheet-music-collection/

5. In 1846 Antoine-Joseph Romagnesi divided the romance into several different categories, attesting to the fragmentation and broadening out of the genre. He listed these as romances sentimentales, mélodies reveuses et grave, chants héroïque et fortement rhythmés, romances passionnées et dramatiques and chansonnettes. See Romagnesi, L'Art de chanter les romances, les chansonnettes et les nocturnes et généralement toute la musique du salon (Paris: Chez l'auteur, 1846), 16.

6. Quoted in David Tunley, Salons, Singers and Songs: A Background to Romantic French Song, 1830-1870 (Aldershot: Ashgate, 2002), 8. 
$16.5 \mathrm{~cm} \times 26 \mathrm{~cm}$. In most cases, the piano-vocal music consisted of a single sheet folded into a folio to yield four pages (one cover page and two pages of music), occasionally with a supplement page for additional verses or couplets. Vocal genres including the scène dramatique, scène comique and the mélodie tend to be many pages longer. The most frequently represented forms of the first half of the nineteenth century were the romance (including its various subgenres) and solo piano music consisting of arrangements of popular opera tunes and dance music genres including the waltz, the polka and the quadrille. These were printed in the large format, on good-quality paper, with a cover image illustrated by lithography and sold for two to three francs, with some of the lengthier piano pieces costing up to 7.50 francs. With the rise in popularity of the cafés-concerts by mid-century and the subsequent broadening of the market for commercial sheet music, publishers began issuing prints of chansons in the smaller format and at a reduced cost, from 35 centimes to one franc. The lower price is reflected in the product: the paper is often of mediocre quality, the music is printed using lithography and the score contains only the vocal melody and the text. Publishers still offered piano-vocal scores of café-concert music in larger format, but at an increased cost. According to François Caradec and Alain Weill, who have written on the history of the café-concert, music publishers would often create a modest print run of about one hundred copies in the larger format on good-quality paper and much more extensive print runs of the smaller format. ${ }^{7}$

One important property of much sheet music of the period is the lists of music available from French music publishers that were printed on the back pages. Publishers advertised works from their catalogues and listed dozens to hundreds of pieces of sheet music. As such, these lists provide valuable insight into and a wealth of information (often not available elsewhere) about the music in circulation at the time of publication, thereby providing clues to the relative popularity of certain genres, composers and themes. In addition to marketing publications via printed sheet music, several publishing houses also owned journals and used them as mediums through which to advertise and distribute

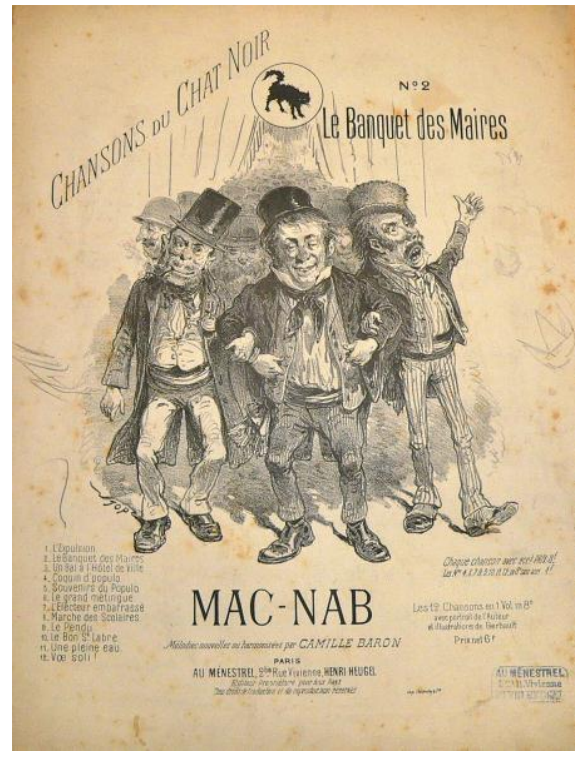

Figure 1. "No. 2, Le Banquet des Maires," lyrics by Maurice Mac-Nab, music by Camille Baron. Chanson. Chansons du Chat Noir. Piano-vocal score, 3 francs. Paris, Au Ménestrel [1892]. Lithography by Stop (Pierre Gabriel More-Retz, 1825-1889). This song is part of a set of twelve chansons (listed on the cover page) created by MacNab for the Chat Noir, founded in 1881 by Rodolphe Salis and one of the most important and best-known cabarets artistiques of the period. their sheet music (fig. 1). In music journals such as Le Ménestrel, La France musicale and La Revue et Gazette musicale de Paris, journal subscribers were provided with complementary

7. François Caradec and Alain Weill, Le café-concert (1848-1914), rev. $2^{\text {nd }}$ ed., (Paris: Fayard, 2007), 139. 
copies of new sheet music publications on a regular basis. Many of the romances in the McGill collection published between 1830 and 1860 come from these journals. As well, journals dedicated specifically to the chanson were established in the second half of the century. The McGill collection includes several dozen issues of one such journal, Les Chansons illustrées, which included a portrait of a café-concert singer as the cover illustration for each issue and also contained a small selection of chansons, monologues, duets and comic sketches.

One of the strengths of the McGill collection is the existence of the aforementioned proof prints. They reveal certain aspects of the creation of the artwork and the publishing process, as well as the various ways the music circulated within social and cultural networks. There are folders containing "clean" copies of the illustrations on very high-quality paper. They are without printed titles, names of composers, lyricists or accompanying music. Some include song titles written in pencil, likely indicating for which song the artwork was intended (fig. 2). A few cover pages exist as incomplete drafts or working copies in which the illustrator seems to be experimenting with different ways of presenting

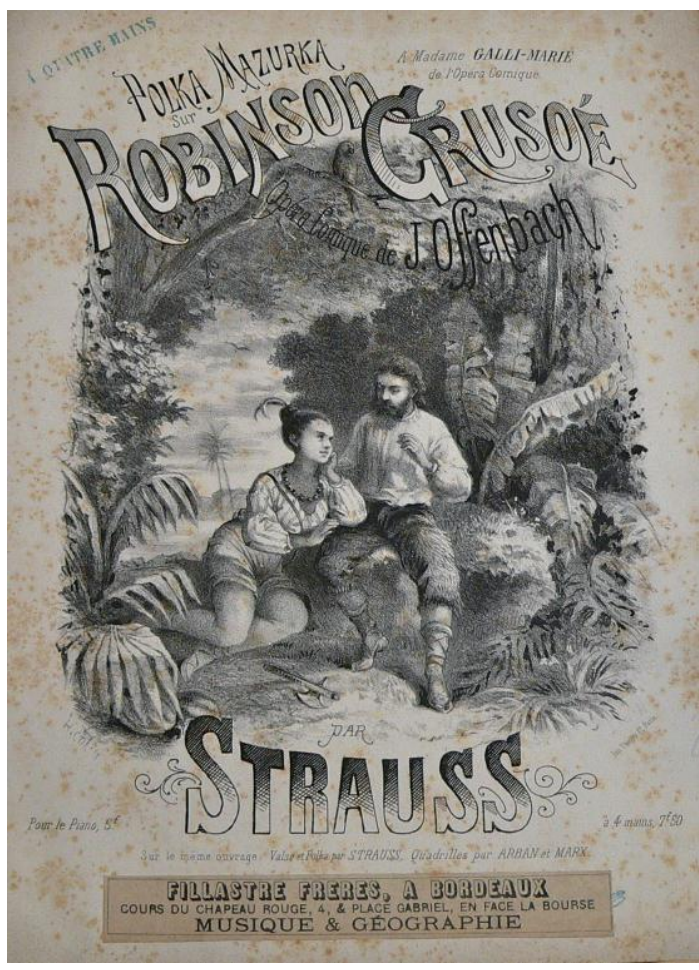

Figure 2. "Polka-mazurka sur Robinson Crusoé, opéra comique de J. Offenbach," arrangement by Strauss. Four-hand piano arrangement, 7.50 francs. Bordeaux, Fillastre frères. Printed dedication: “À Madame Galli-Marié de l'Opéra Comique." Offenbach's work was premièred at the Opéra Comique in 1867. Célestine Galli-Marié (1840-1905), best known as the creator of the title role in Bizet's Carmen, performed the role of Vendredi; at her side is Achille-Félix Montaubry (1826-1898), the tenor who sang the role of Robinson Crusoé. The lithograph is a reproduction of the original poster created by $\mathrm{H}$. Colin, and the scene depicted is taken from the first tableau in the second act. The McGill collection contains a proof copy of the lithograph in addition to the cover page of this arrangement. the image along with the arrangement of the work's title and the names of the composer, lyricist and dedicatees. As well, the collection contains a small number of original sketches of some of the artwork used for sheet music illustration. These are usually unsigned and have been placed in close proximity to the final print version.

The collection also contains dozens of individual pieces of piano-vocal sheet music that might have been intended as proof copies by the publisher. They might have been presented to an individual-perhaps the composer, lyricist or the patron who commissioned the printing - as a representative sample of the print run. The publisher usually writes a signed statement to this effect on the front cover. The statement on the cover of lyricist Alfred Goy and composer Alfred 
Clemenceau's romance, "Une rose de tes cheveux," for example, reads: "Nous certifions l'édition en tout conforme au présent exemplaire. Paris 24 octobre 1839. Lemoine \& Cie." ("We certify that the edition conforms completely to the present copy") (fig. 3). In rare cases, corrections were made on these proof copies, thus providing a written record of the authors' revisions.

Several pieces in the collection carry a signed dedication from the lyricist or the composer to a friend, a fellow musician or a singer, suggesting the music was given as a gift. The reasons for circulating music in this manner varied considerably, but it seems highly probable that composers, lyricists and publishers were motivated to circulate their pieces to those people who would perform-and thus promote-their music. A number of the dedicatees in the collection have been identified as prominent concert, salon and/or opera singers. Therefore this music provides potentially exceptional insights into ephemeral (and thus largely overlooked) musical communities, networks of performers, composers, lyricists and the music's performance contexts.

What is more, preliminary research shows that singers in particular began using commercial sheet music as tools of self-promotion and image-making. Toward mid-century, cover page illustrations sometimes included a portrait of the singer, rather than an image inspired from the song's subject. Madame Emilie Gaveaux-Sabatier (née Bénazet), for example, was a well-known salon singer. She possessed a flexible, brilliant voice and according to her contemporaries, could easily have pursued a career on the stage, were it not for her social position and marital status. Although Gaveaux-Sabatier did not become an opera star, she was a celebrity in her own right. More than thirty songs, some of which feature her portrait, are dedicated to her in the McGill collection alone (fig. 4). Caroline Carvalho (née Marie Félix-Miolan, 1827-1895) also sang in salons and in

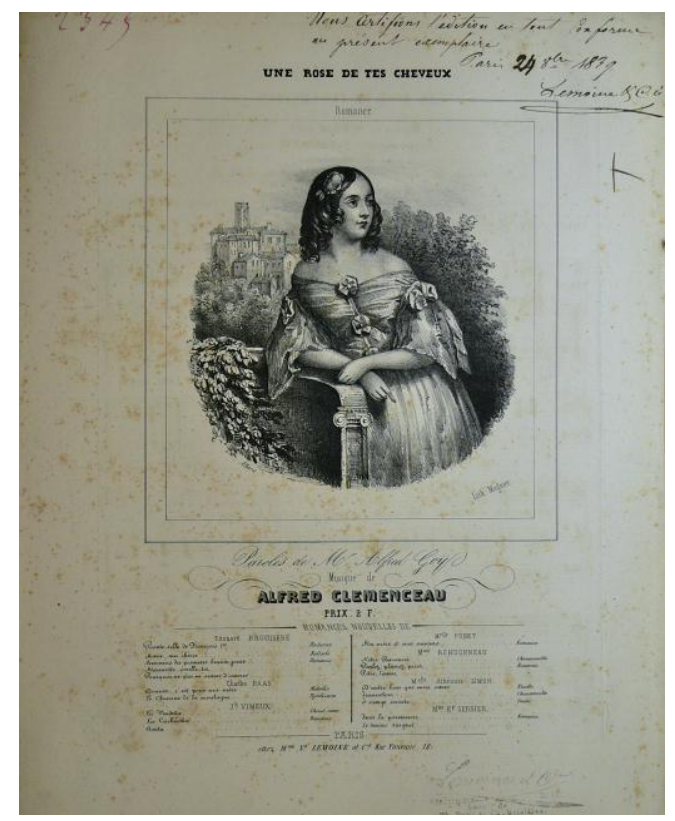

Figure 3. "Une rose de tes cheveux," lyrics by Alfred Goy, music by Alfred Clémenceau. Romance. Piano-vocal score, 2 francs. Paris, Lemoine \& Cie. Lithography by Allard.

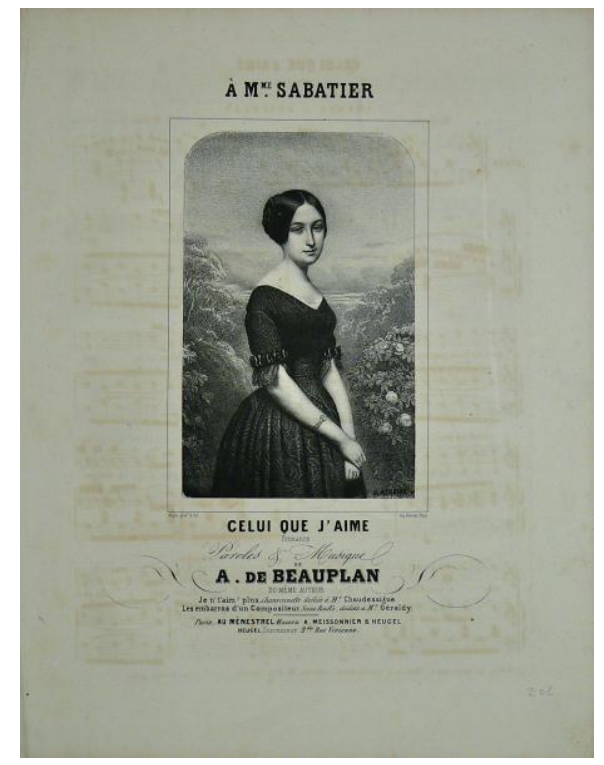

Figure 4. "Celui que j'aime," lyrics and music by Amédée de Beauplan. Romance. Piano-vocal score. Paris, Au Ménestrel. Printed dedication: "À Mme Sabatier." Lithography by Marie-Alexandre Alophe. The cover page image is an actual portrait of Emilie Gaveaux-Sabatier; the McGill collection contains at least three other songs with her portrait as the cover image. The artwork was originally created by Alophe for the Paris Salon of 1843. 
concerts before launching her operatic career. She participated in many of the concerts hosted by Le Ménestrel and promoted certain songs published by the journal. As a result, her performing activities were followed closely by the journal's writers. This particular case reveals the widespread mutually beneficial relationships that sprung up between publishing houses and performers as they were mediated through the publication of commercial sheet music.

This kind of promotion of performers through commercial sheet music and vice versa continued and intensified as the café-concert (and later, music-hall) flourished from the middle to the end of the nineteenth century. In this repertoire, the names of the performer and the venue-as well as singers who later performed the song at different venues - were advertised on the sheet music covers. By analyzing these dedications and venue listings, the performing repertoires of certain star café-concert singers can be reconstructed and the circulation of the music through different venues traced. The collection contains large numbers of songs dedicated to some of the most important café-concert singers of the period:

- Mlle Thérésa (née Eugénie Emma Valladon, 1837-1913), who sang from the 1860s to the 1890s, mainly at the Alcazar d'été and Alcazar d'hiver, and was hailed as café-concert's first vedette

- Jeanne Bloch (1858-1916), the vedette at la Scala who created the French version of a popular American song, Tha-ma-ra-Boum-di-hé

- Anna Judic (née Anne-Marie-Louise Damiens, 1849-1911), who created the role type diseuse and became a well-known operetta singer (she created a role in Offenbach's Le Roi carotte and later took over Hortense Schneider's role in La Belle Hélène)

- Yvette Guilbert (née Emma Laure Esther Guilbert, 1865-1944), who took over and redefined the diseuse role type and later recorded many of her most famous songs

- Polin (né Pierre-Paul Marsalès, 1863-1927), who debuted in 1886 and created the role type of the comique troupier

- Paulus (né Jean-Paulin Habans, 1845-1908), probably the biggest star of the caféconcert, who created the new role type of the gambillard

As can be seen from the small sample above, the most famous café-concert singers created their own role types, which were carefully defined through their choice of repertoire and their performance styles. The next generation of singers took up these role types and redefined them. The repertoire in the McGill collection, therefore, provides an opportunity to re-create 
and better understand these particular role types as well as to determine the ways the song's subject, text and music all contributed to their definition (fig. 5).

\section{Further avenues of research}

The dominant forms of sheet music published in earlyand mid-nineteenth-century France, the romance and mélodie and various related subgenres (orientale, scène dramatique, tyrolienne, pastorale, chansonnette, légende, etc.), are represented in the collection by well-known composers of the period: Loïsa Puget, Amédée de Beauplan, Hippolyte Monpou, Louis Clapisson, Albert Grisar, Jacques Offenbach, Victor Massé and J.B. Weckerlin. The romance, often disparaged as "easy music," 8 has been relatively neglected in musicological scholarship. Fritz Noske, in his monograph French Song from Berlioz to Duparc (first published in French in 1954; revised and translated into English in 1970), focused predominately on the mélodie and traced its evolution as a product of three events: the decline in artistic quality of the romance, the introduction of Schubert's lieder in France, and the influence of new Romantic poetry. ${ }^{9}$ He harshly condemned the romance in the following terms: "it would be difficult to find a single page of real artistic value in the entire production of a quarter century." ${ }^{10} \mathrm{~A}$ few scholars in French musicology have since challenged Noske's pronunciation on the romance as well as his theory on the mélodie's evolution. Kitti Messina, for example, has shown that pieces marked as romance and mélodie shared many generic features until the final decades of the nineteenth century, ${ }^{11}$ and William Cheng has perceptively linked the disparagement of the romanceperceived as a feminine and perhaps even femininizing genre-with the gendered discourse on

8. See discussion in William Cheng, "Hearts for Sale: The French Romance and the Sexual Traffic of Musical Mimicry," 19th-Century Music 35, no. 1 (2011): 34-71, esp. 41-49.

9. Fritz Noske, French Song from Berlioz to Duparc: The Origin and Development of the Mélodie, 2nd ed., trans. Rita Benton (New York: Dover, 1970), 1.

10. Noske, 11.

11. Kitti Messina, "Mélodie et romance au milieu du XIXe siècle: Points communs et divergences," Revue de musicologie 94, no. 1 (2008): 59-90. 
musical genres and music making. ${ }^{12}$ With well over a thousand romances and melodies in the McGill collection (as well as many of Schubert's lieder in French translation as they would have been introduced and circulated in France in the second quarter of the nineteenth century), scholars have an exceptional opportunity to study the ways in which these genres influenced one another and possibly challenge and expand existing histories of this music.

In addition to questions of genre, the sheet music collection provides a fascinating glimpse into the cultural constructions of femininity and masculinity; social mores such as marriage, fidelity and inheritance and contemporary perceptions of the oriental "Other"; as well as music composed or produced to commemorate important historic events, such as the Franco-Prussian conflict of 1870-1871 and the Paris commune; the Exposition universelle held in Paris in 1855, 1867, 1878,

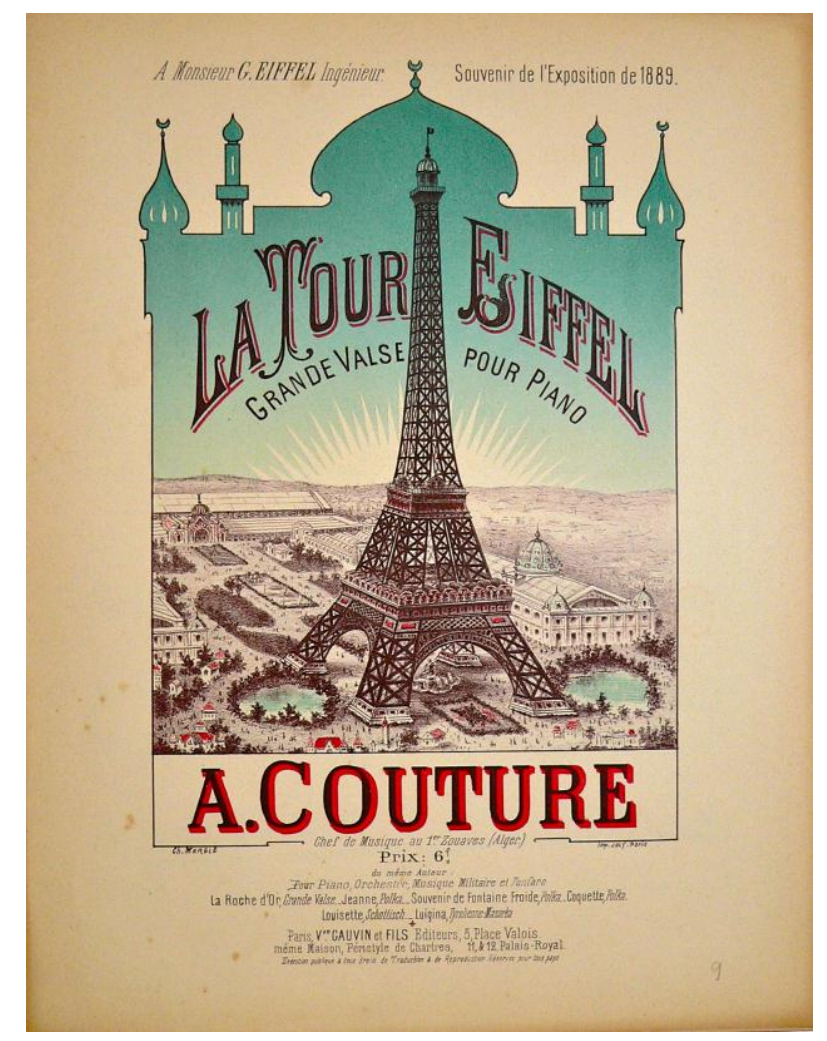

Figure 6. "La Tour Eiffel/ grand valse pour piano," music by A. Couture. Waltz. Piano score, 6 francs. Paris, Veuve Gauvin et fils. Lithography by Ch. Mergié. Printed dedication: “À Monsieur G. Eiffel Ingénieur / Souvenir de l’Exposition de 1889." 1889 and 1900 (fig. 6); the women's suffrage movement; and the events leading up to the beatification of Jeanne d'Arc in 1909. It seems clear the composition, performance, publication and distribution of this music both reflected and participated in the construction of social, cultural and political values and ideals. The vast array of sheet music in the McGill collection promises to assist scholars in exploring and evaluating the complex network of relationships that combined to form the rich musical life of nineteenth- and early twentieth-century France.

\section{Current and future plans for the collection}

Going forward, the McGill collection of nineteenth- and early twentieth-century French sheet music will be catalogued and partially digitized. ${ }^{13}$ An online full-text database will include an extensive controlled vocabulary intended to assist scholars in identifying specific musical genres

12. William Cheng, "Hearts for Sale: The French Romance and the Sexual Traffic of Musical Mimicry," 19thCentury Music 35, no. 1 (2011): 34-71.

13. There is a card catalogue for the collection. Some of the pieces in the McGill collection are also held by the Bibliothèque nationale de France. Digital versions can be accessed through their web-based repository, Gallica. 
and iconographic elements. Information about the collection and its contents will be found on the following website: http://hypatia.music.mcgill.ca/mdmlsheet.html.

As well, Kimberly White will deliver two papers on her research: one at a meeting of the New York State-St. Lawrence Chapter of the American Musicological Society in Ottawa, Ontario, on April 27, 2013, and another at the Canadian University Music Society Conference (in coordination with the Congress of the Humanities and Social Sciences) in Victoria, British Columbia, on June 8,2013 . These presentations will examine the relationships that were established between publishing houses and the singers who actively promoted their music via performances in salons and concerts and explore how such marketing strategies contributed to a flourishing celebrity culture in nineteenth-century France. Electronic copies of the talks will be provided on the above website and an expanded version of this research project will be prepared for publication in 2014. 